\title{
Development of Recognition Qur'an Letter Foundation for Beginners on Indonesian Islamic Foundation Waqf (IIWF)
}

\author{
$1^{\text {st }}$ Nurhayati $^{1}, 2^{\text {nd }}$ Muhammad Farouq $^{1}, 3^{\text {rd }}$ Hendra Bayu Suseno ${ }^{1}, 4^{\text {th }}$ Andrew Fiade ${ }^{1}, 5^{\text {th }}$ \\ Busman $^{2}$ \\ \{nurhayati@uinjkt.ac.id ${ }^{1}$,m.farouq@mhs.uinjkt.ac.id, hendra.bayu@uinjkt.ac.id ${ }^{1}$, \\ andrew.fiade@uinjkt.ac.id ${ }^{1}$,busman.sjam@gmail.com ${ }^{2}$ \}
}

UIN Syarif Hidayatullah, Department of Informatics, Jakarta, Indonesia ${ }^{1}$, School of Economics Gotong Royong, Department of Management, Jakarta, Indonesia ${ }^{2}$

\begin{abstract}
The lifestyle changes follower by the changing times. The use of technology, such as smart phones and computers that spread blamed the cause of the ballooning illiterate Qur'an to 54\%. Indonesian Foundation for Islamic Waqf Foundation (IIWF) sees the tools of this technology can even be used as part of a literacy Qur'an. This study aims to provide the application of learning to read the Qur'an for the foundation IIWF. Development of the system used in the study is the development of methods Multimedia versions of Luther-Sutopo with the following approach: Concept, Design, Material Collecting, Assembly, Testing, and Distribution. Media development learn to read the Qur'an was created with the PHP programming language for websites and Flash Action Script applications for learning to read the Qur'an. The results of this application are the website of the foundation IIWF that allows for downloading e-books and interactive applications to read the Qur'an. Based on Black Box testing and User Acceptance User to user, IIWF foundation, showed that applications that have been created have been functioning properly, satisfy the desires of the foundation IIWF and can help the foundation in the fight against illiteracy IIWF Qur'an to Muslims in Indonesia.
\end{abstract}

Keywords: Applications, the Qur'an, Hijaiya, Flash, PHP, MySQL.

\section{Introduction}

The literacy rate of the Holy Qur'an in Indonesia is high. Based on data from the National Economic Social Survey of the Central Bureau of Statistics (BPS SUSENAS) in 2013 that there was about 54 percent of the total population of Muslims in Indonesia who could not read the Qur'an (CBS, 2013). The illiteracy rate is more than half of this is very worrying for Muslims in Indonesia, because the ability to read the Qur'an properly is key for Muslims to be able to understand and examine the contents of the Qur'an as a source of goodness for life the world and the hereafter.

Education in reading the Qur'an in Indonesia is quite diverse, including Taman Pendidikan Al-Qur'an (TPQ), Islamic Kindergarten (TK Islam), Raudatul Athfal (RA) and so on. However, the education of the Qur'an that already exist, in particular the previously mentioned cannot cover the entirety of Muslims in Indonesia, both the number and age. This 
problem is also present in public education, which may be the solution can be used also in the teaching of reading the Qur'an in Indonesia, namely distance education.

Distance education in Indonesia is not a new thing in Indonesia. One example is the website of the Center for Information and Communication Technology Education and Culture (Pustekkom) belonging to the Ministry of Education and Culture. Website Pustekkom is a means for self-learning, with amenities such as TV-Education, School of Electronic Books that can be downloaded in the form of an e-book, Video Learning and so on. The main component of distance education facilities owned by Pustekkom is an application that is embedded on a website. However, to be able to use this educational facility, the user is required to have internet. Internet is one of example of a part of the Information and Communication Technology is growing very rapidly in Indonesia.

According to the census conducted by the Association of Indonesian Internet Service Provider (APJII), there is about 60 million internet users in Indonesia in 2012. In addition, APJII also calculates internet users in Indonesia will reach 139 million by the end of 2015 . Based on these data, the authors assess that distance education using an application that is embedded on the website are suitable, considering the number of Internet users in Indonesia and its development every year. Indonesian Islamic Waqf Foundation (IIWF) was established in 2010, has many ideas to promote education and Islamic Da'wah. Among blue print activity is to provide compensation to the students or students who are specializing to memorize the Koran. The compensation during this new award is in the form of improved nutrition for children in Kampung Kramat, Setu village in East Jakarta. When the author refers to survey results released by BPS, IIWF keen to develop its web by providing educational services Qur'an is on-line, as well as the website owned by Pustekkom. The especially is for beginners, regardless of age.

To develop this application, we used interactive multimedia elements, by using Adobe Flash media application that is embedded in the foundation website IIWF. The author chose the Adobe Flash media because other than flash can be embedded on websites, flash applications can present the desired multimedia elements on recognition application letter writer Quran for beginners, such as animation, sound, pictures, and so on. For this reason, the authors developed an application letter recognition Quran with multimedia development methods Luther-Sutopo version is poured on a thesis entitled: "Making Applications Introduction Letter Quran for Beginners at the Indonesian Foundation for Islamic Waqf Foundation (IIWF)".

\section{Review of Literature and Basic Theory}

\subsection{Multimedia Development Method}

According to [9 and 12] to develop a program based applications multimedia needed six stage multimedia development, namely the concept (concept), design (design), material collecting (collecting materials), assembly (manufacture), testing (testing) and distribution (distribution). Multimedia application development cycle can be seen in the following figure1. 


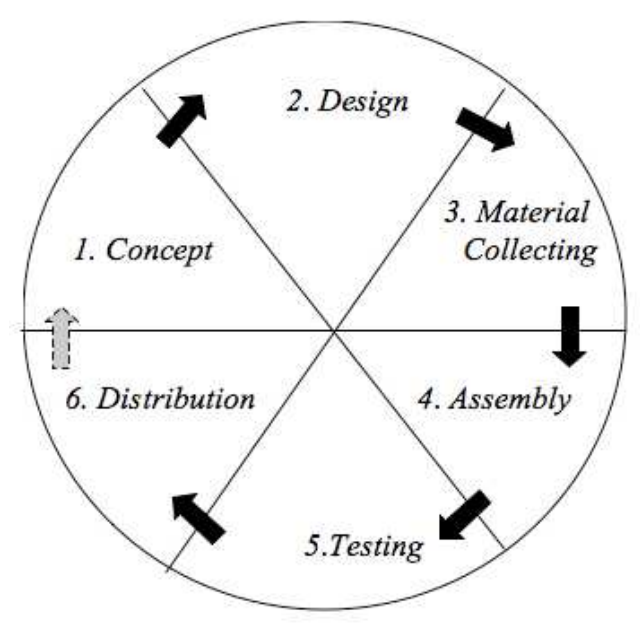

Figure 1. Multimedia Development Method [9]

\section{Concept}

The concept phase is to determine the purpose, audience identification, applications, application purpose, common specifications, the basic rules for the design such as the size of the application, the target and others. Noteworthy at this stage is to determine the purpose of the use of multimedia as well as the audience. The purpose the audience influence on the nuances of multimedia, as reflecting the identity of organizations that want information to the audience. Multimedia is said to be communicative if it can understand the characteristics of the user.

2. Design

At this stage to make detailed specification of the project architecture, style and material needs for the project. Specifications made detailed enough so that at a later stage is not required new decision. There are three kinds of design, including:

a) Multimedia-Based Design.

This design method is developed from design method of making a movie using story board. In the development of multimedia require interactive aspects, so that is equipped with a flowchart view. ${ }^{[9]}$

b) Structural Design Navigation.

Navigation structure gives an overview link from one page to another page. Multimedia navigation structure used in nonlinear and adaptation of web design ${ }^{[12]}$

c) Object-Oriented Design.

Object-oriented design methods are design methods in which multimedia components expressed as objects. Object oriented design used on many systems that consists of objects, such as geographic information systems and others. 


\section{Material Collecting}

The collection of material can be done in parallel with the assembly stage. At this stage of collecting material such as images, animation, audio, photo and others needed at a later stage.

4. Assembly (Making)

Manufacture is the stage where all the multimedia objects created. Making an application based on the story board and flowchart derived from the design stage.

5. Testing (Testing)

Tests performed after the completion of the manufacture and all data has been entered. First performed in a modular testing to ascertain whether the results as desired. And do also test whether the application can run well in the user's environment.

6. Distribution (Distribution)

Distribution stage is the stage where do multiplication applications. Doubling can use a flash disk, a CD ROM and will be also distributed on the web which will then be displayed on the internet. This phase will be also an evaluation of a multimedia product. The evaluation was done in order to develop a better system.Maintaining the Integrity of the Specifications.

\subsection{Teaching Reading the Qur'an in Indonesia}

Al-Qur'an is a way of life for Muslims as individuals, families, and communities. The Qur'an was revealed to the Prophet Muhammad in Arabic. For Indonesian Muslims to understand the Qur'an double effort required to learn Arabic, at least to be able to read and understand it in translation. Teaching Quran walisongo on students, next to the scholars.

In learning the Qur'an until today (modern times) is still known several methods of reading the Qur'an, among others :[2]

a) Sound Method

b) Method of Imitating

c) Rote Method

d) Method of Assignment

e) Libat Method (See, Read, Write)

f) Al-Jabary Method

g) Method Lu'ba (See, Change, Read, and Memorize)

h) Al-Bidayah Method

i) Method 3 hours + Iqro' practice card

j) Mixed Methods

The method is already growing mix of them: Al-Barqy method, Iqro', and Qiroaty. From each of these methods certainly has strengths and weaknesses in learning to read the Qur'an that has developed in the community we are today. However, the method has been widely used method Iqro' and there by creating a more Qiroaty education institutions Qur'an which we now know. As the TKA-TPA, TKAL-TPAL, TQA.

\section{Research Methodology}

\subsection{Data Collecting Method}

Methods of data collection is done by writer is literature study and field studies by conducting interviews to the foundation IIWF. 


\subsection{Systems Development Method}

System development methods that I use in this study are the Multimedia Development Method version of Luther-Sutopo.

\section{Concept}

At this stage, the authors determine the purpose and the target users of the application to be made. In addition, the authors also specify the type of application to be made and the purpose of the application.

\section{Design}

After determining what is required in making this application, the authors proceed to the design stage. At this stage the author interacts with the client, in this research is the foundation IIWF, to develop a prototype of this system, including what is processed by this system and its input and output. Users performed interactively design allows clients to understand, modify and approve a system that has been in accordance with the wishes.

\section{Material Collecting}

At this stage, the authors collected the materials required in making application letter recognition this Qur'an. These materials include the key of the letter hijaiyah, voice pronunciation of each letter, and so on.

\section{Assembly}

Assembly stage is the stage of making all objects or multimedia materials. Making the applications based on the design stage, such as story boards, flow charts, and / or navigation structure.

\section{Testing}

Phase testing is performed after the assembly phase is completed, which is done by running the application / program if there is a mistake or not. Phase testing conducted by the authors, there are two phases, namely testing Black-Box and User Acceptance Test with IIWF foundation.

\section{Distribution}

At this stage, the application that has been completed is stored in a storage medium. Compression applications will be carried out if the media storage that is too small for the application, the abbreviations and the acronyms.

\subsection{Frameworkd of Thinking}




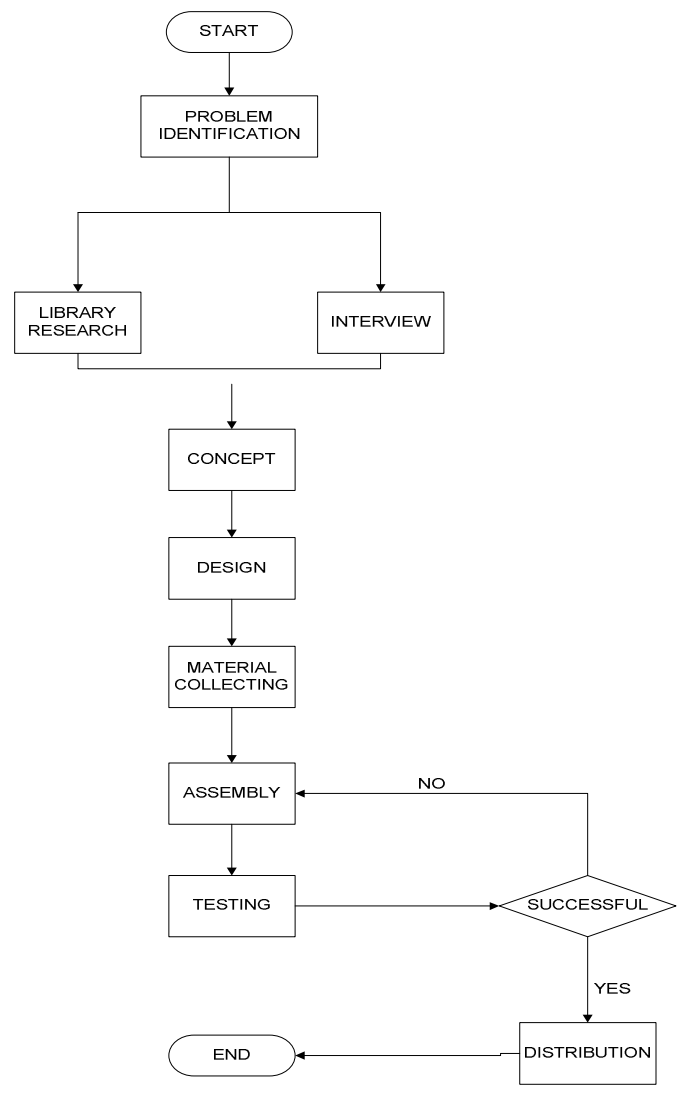

Figure 2. Framework

\subsection{Concept}

To design a website of applications introduction letter of the Qur'an to be embedded in a web IIWF, the author has conducted an interview with the founder of the Indonesian two Islamic Waqf Foundation (IIWF). The interview list attached. From these interviews the author may define the concept of the application to be made. The concept of the application is as follows.

Table 1. Concept Application

\begin{tabular}{|l|l|}
\hline Title: & $\begin{array}{l}\text { KNOWING RESEARCH RESULT QUR'AN'S } \\
\text { LETTERS }\end{array}$ \\
\hline Audience: & Internet user \\
\hline Image: & $\begin{array}{l}\bullet \quad \text { Navigation buttons are the } \\
\text { author created with tools in Adobe } \\
\end{array}$ \\
& $\begin{array}{l}\text { Flash Pro CC. } \\
\bullet \quad \text { Letter Hijaiyah the Writers } \\
\text { Create using Adobe Illustrator CC. }\end{array}$ \\
\hline
\end{tabular}




\begin{tabular}{|l|l|}
\hline & \multicolumn{1}{|c|}{\begin{tabular}{c} 
IIWF. Photographs of the foundation \\
\hline Audio:
\end{tabular}} \\
\hline Duration: & A recording saying the letter hijaiyah \\
\hline Animation: & $\begin{array}{l}\text { Animation motion tween to the turn of the } \\
\text { scene, the menu key and the letter } \\
\text { hijaiyah. }\end{array}$ \\
\hline $\begin{array}{l}\text { Interactivity } \\
\text { Next: }\end{array}$ & $\begin{array}{l}\text { Users can use the navigation keys to go to } \\
\text { the material before and after, and can } \\
\text { return to the main menu. }\end{array}$ \\
\hline
\end{tabular}

\subsection{Design}

Once the process is complete concept, the authors proceed to the next step, namely the design process. At this stage, the authors determine the design of the application to be made, based on data from interviews and concepts that have been determined.

Table 2. Design Process

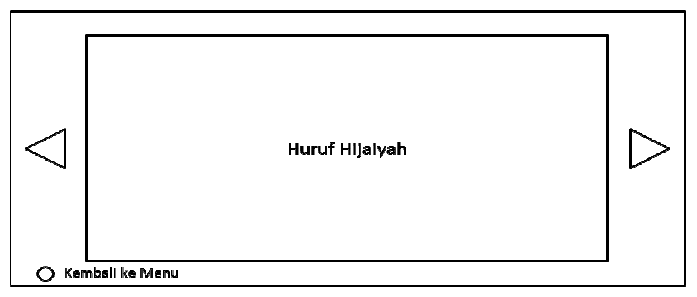

\subsection{Material Collecting}

Before getting into the making of the application, the authors first collecting material that will be used by the application. In this case, the letter keys hijaiyah, navigation buttons and sound of each letter hijaiyah.

\subsection{Assembly}

Once the material for the manufacture of finished applications are collected, the authors continue at the stage of assembly, namely the preparation of the application in accordance with pre-determined at the stage concept and design, using materials that have been collected at the stage of collecting material.

Table 3. Design Application 


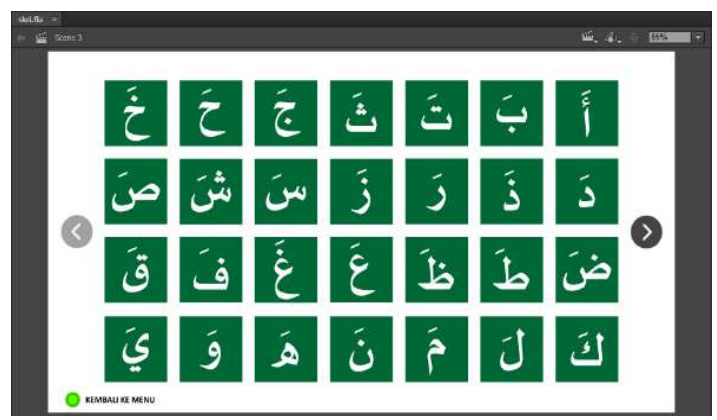

\subsection{Testing}

This phase is the testing phase of the program by the author. At this stage, We uses external testing (BlackBox) and User Acceptance Test. This test did check one by one by using the link table testing whether the link has been in line with expectations or not.

\subsection{Distribution}

At this stage, We upload the files that are ready to hosting that has been prepared by the foundation IIWF.

\section{Conclusion}

\subsection{Conclusion}

The author has made an application letter recognition Quran for beginners on the foundations Indonesian Islamic Waqf Foundation using Flash applications to be embedded on a website owned by a foundation. Based on the results of testing Black Box and User Acceptance Test has been conducted by the author with the foundation IIWF, the applications worked well, fulfilling desired by the foundation IIWF and foundations states that the application can help the foundation in the fight against level Al-Qur'an illiteracy in Indonesia.

\subsection{Suggestion}

The author realized in conducting research still has short comings. Therefore, we suggest developing the study, among other things:

a. The addition of the subject matter. Now, the application is limited only in the introduction letter of the Qur'an alone along with dignity, hence the importance of learning material after hijaiyah letter recognition, so that users getting benefit from these applications with more leverage.

b. The addition of support for browser-based mobile / Smartphone, so that applications can be used in Smartphone's, is not limited to computers only.

\section{References}


[1] Aditya Panji (2013). Tech In Asia Makin Agresif di Indonesia. Jakarta: http://tekno.kompas.com, 8/10/2013

[2] Ahmad, M. Syatiri, dkk., Pedoman Pengajian Al-Qur'an bagi Anak-anak dan Rekaman Diskusi Penyusunan Pedoman Pengajian Al-Qur'an bagi Anak-anak, Jakarta: Proyek Penerangan Bimbingan dan Dakwah / Khutab Agama Islam Pusat Ditjen Bimas Islam dan Urusan Haji Depag RI, 1982/1983.

[3] Binanto, Iwan. 2010. Multimedia Digital - Dasar Teori dan Pengembangan. Yogyakarta.

[4] BPS, Susenas. 2013. Survei Sosial Ekonomi Nasional 2013 Kor Gabungan.

[5] Diginnovac, Arry Maulana, Karina Nasution. 2008. Draw and Animate with Flash. Jakarta.

[6] Febrian, Jack. 2007. Kamus Komputer danTeknologi Informasi. Penerbit Informatika. Bandung

[7] Hafidz Muftisany (2014). Yayasan Al-Fathanah Cirebon MembumikanPengajaran Al-Quran. Jakarta: http://www.republika.co.id/berita/14/11/21.

[8] Kementerian Agama, BadanLitbangdanDiklat (2014). Laporan Tahunan Kehidupan Keagamaan di Indonesia 2013. Jakarta: Badan Litbang dan Diklat Kementerian Agama RI.

[9] Luther, A. C., 1994, Authoring Interactive Multimedia, Academic Press, Inc., Massachusettes.

[10] Moh. Nazir. Ph.D, 2005, Metode Penelitian. Ghalia Indonesia. Bogor.

[11] Nusa Putra, S.Fil, M.Pd. Dr. (2011). Research \& Development, Penelitian dan Pengembangan, Suatu Pengantar. Jakarta: PT Raja Grafindo Persada.

[12] Ariesto Hadi, Sutopo, 2003, Multimedia Interaktif dan Flash, PT Graha Ilmu. Yogyakarta 